\title{
Water uptake dynamics in soybean seeds: influence in seeds performance and DNA integrity
}

\author{
Lisiane Sartori Pereira ${ }^{1}$ (D) Tathiana Elisa Masetto $^{1^{*}}$ (D)

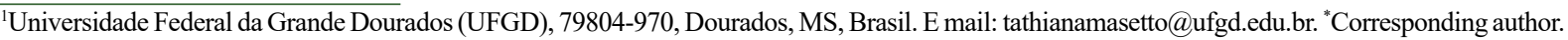

\begin{abstract}
Relationships among water uptake rate and temperatures were investigated in five soybean seeds lots cv. M 6410 IPRO. Germination, field emergence and electrical conductivity tests were applied to determine seed performance after fast (complete immersion in water), control (moist substrate) and slow (moist atmosphere) imbibitions both at $20{ }^{\circ} \mathrm{C}$ and $30{ }^{\circ} \mathrm{C}$. The fresh weight increment over time in soybean seeds during imbibition was recorded. In parallel, analysis of the DNA integrity of seedlings obtained from such seeds was performed in gel electrophoresis. Absorption pattern of soybean seeds were similar among temperatures, but absorption characteristics vary with time progress according to the way of water entrance into the seeds. Upon fast imbibition seeds germinated lower than non-fast-imbibed seeds, besides loss of seed performance. In contrast, slow-imbibed seeds showed high germination, low abnormal seedlings and maintenance of seeds performance. DNA isolation from fast imbibed seeds was highly degraded; although, some considerably degraded samples were reported in controlled imbibed seeds and the best preserved DNA was found in slow-imbibed seeds. The pattern of DNA degradation is typically passive or non programmed cell death. Our results showed it is important to consider the water uptake rate during germination test, since DNA integrity plays a critical role during seed imbibition, preserving soybean seed performance.
\end{abstract}

Key words: DNA disassembly, early seed imbibition, germination, passive cell death.

Dinâmica de absorção de água em sementes de soja: influência no desempenho de sementes e integridade do DNA

RESUMO: As relações entre a taxa de embebição em água e temperaturas foram estudadas em cinco lotes de sementes de soja cv. M 6410 IPRO. Testes de germinação, emergência a campo e condutividade elétrica foram aplicados para avaliar o desempenho das sementes após rápida embebição (imersão direta em água), controlada (substrato úmido) e lenta (atmosfera úmida), ambos a $20{ }^{\circ} \mathrm{C}$ e $30{ }^{\circ} \mathrm{C} . \mathrm{O}$ incremento no peso fresco das sementes durante a embebição foi registrado. Paralelamente, a integridade do DNA de plântulas oriundas das sementes foi avaliado em gel por eletroforese. O padrão de embebição das sementes de soja foi similar entre as temperaturas, mas houve variações com o tempo de acordo com o modo de entrada de água nas sementes. Após a embebição rápida, as sementes apresentam menor germinação e desempenho que as sementes submetidas aos demais métodos de embebição. O DNA isolado a partir de sementes que embeberam rapidamente encontrava-se degradado, embora em sementes que foram hidratadas de forma controlada também fosse encontrada degradação do DNA. $O$ DNA mais preservado foi encontrado em sementes que embebem lentamente. O padrão de degradação do DNA é típico de morte passiva ou não programada de células. Os resultados indicam que é importante considerar a taxa de embebição em água durante o teste de germinação, pois a integridade do DNA desempenha uma função importante durante a embebição, preservando o desempenho das sementes de soja. Palavras-chave: desintegração do DNA, embebição inicial de sementes, germinação, morte passiva de células.

\section{INTRODUCTION}

Seed germination is a complex and tightly regulated process which starts with water absorption by the dry seed and ends when radicle elongates. Its achievement requires a synchronized attainment of many cellular processes including DNA repair, protein synthesis or membrane reorganization (WEITBRECHT et al., 2011; BEWLEY et al., 2013). Since membrane reorganization is one of the major events occurring during seed imbibition, and since cold temperatures are known to modify membrane phospholipids, it relies on the accumulation of saturated or poorly unsaturated fatty acids, whatever the phospholipid class (NOBLET et al., 2017).

It is worth noting that seed imbibition is an important process in the plant life cycle and determines whether seed germination and plant growth will be successful or not (RIBEIRO et al., 2015). Even DNA does not escape the severity of drying and rehydration without some damage, and repair is an early priority. Thus, it is anticipated that following imbibition the synthesis of enzymes and compounds to limit and repair cellular damage is prevalent (NONOGAKI et al., 2006). 
It is; therefore, surprising that the integrity of nucleic acids during seed imbibition, and, perhaps more importantly upon different imbibition rate has received relatively little attention in the recent literature, especially until the complete seedling establishment. The complex trait of soybean seed imbibition prior to germination has been demonstrated especially due to the importance of seed quality to the crop establishment and sustainable agricultural productivity. Rapid seed imbibition leads to the leaching of more electrolytes before the cell membranes have time to reorganize, even under slower hydration conditions (ROSSETTO et al., 1997) and in different physiological quality and contrasting coats of soybean seeds (CAVARIANI et al., 2009; GRIS et al., 2010, BAHRY et al., 2017).

In most cases, loss of seed vigor neither the safeguard genome, as being important markers of quality was not recorded even of great importance to analysis of soybean seed lots. Besides, DNA repair plays a critical role during seed imbibition, preserving seed vigor (BALESTRAZZI et al., 2011) mainly during the early imbibition phase. In agreement with this hypothesis, effective DNA repair takes place only when repair effectors are accessible to the damaged sites (BALESTRAZZI et al., 2015).

Furthermore, it is important to consider water uptake prior seed performance for breeding purposes, seed analysis and crop field. Although, this attempt has already been made by some seed companies, germination characteristics are seldom included in breeding programs (NONOGAKI, 2006) and could help analyzing the real physiological potential of seeds lots. We hypothesized soybean seed performance behaves differently according to water absorption rate and to temperature, since slow rehydration if not beneficial, at least is not partially damaging to the seed, even at lower temperature. We evaluated germination and seeds performance of soybean seeds cv. M 6410 IPRO, which is largely cultivated in tropical areas of Brazil central, upon different water uptake rate at two temperatures and its relationship to nucleic acid integrity, especially DNA.

\section{MATERIALS AND METHODS}

Plant material, germination test and seeds performance

Five soybean seeds lots cv. M 6410 IPRO were produced in Dourados, MS, Brazil $\left(22^{\circ}\right.$ $11^{\prime} 44^{\prime \prime} \mathrm{S}$, and $54^{\circ} 56^{\prime} 08^{\prime \prime} \mathrm{W}$ and at an altitude of $430 \mathrm{~m}$ ) from 2017-2018 crop and freshly harvested (85\% germination, $61 \%$ accelerated test, $70 \%$ field emergence and $52,23 \mu \mathrm{S} \mathrm{cm} \mathrm{cm}^{-1} \mathrm{~g}^{-1}$ electrical conductivity, in average - no differences at Tukey's test, $\mathrm{p}>0.05)$. The seeds lots were kept in a cold room $\left(10{ }^{\circ} \mathrm{C}\right.$ and $50 \%$ air relative humidity) for the duration of the study. Initially, seed water content was determined with two replications of 20 seeds per lot were subjected to the oven-drying method, which uses $105 \pm 3{ }^{\circ} \mathrm{C}$ for $24 \mathrm{~h}$ (BRASIL, 2009).

The Rules for seed analysis (BRASIL, 2009) prescribe that soybean seed germination testing should be conducted at the temperatures of 20-30, 25 or $30{ }^{\circ} \mathrm{C}$. Here, we used the temperature of $30{ }^{\circ} \mathrm{C}$ as control and constant $20^{\circ} \mathrm{C}$ to assess the influence of low constant temperature during seeds water uptake. For imbibition experiments, seeds were transferred to beckers filled with distilled water $(100 \mathrm{ml})$ (fast imbibition); or paper roll (two filter papers moistened with $2.5 \mathrm{~mL}$, as being control) or moist atmosphere (slow imbibition) - seeds were spread in a single layer on stainless-steel screens and placed in plastic germination boxes $(11 \times 11 \times 3.5 \mathrm{~cm})$ containing 40 $\mathrm{ml}$ of distilled water at the bottom. The beckers, paper rolls and boxes with the seeds were maintained in chambers at $20{ }^{\circ} \mathrm{C}$ and $30{ }^{\circ} \mathrm{C}$, at constant white light photon flux density of $150 \mu \mathrm{mol}^{-1} \mathrm{~m}^{2} \mathrm{~s}^{-1}$ with a relative humidity (RH) of $70-80 \%$. After 24 h the seeds lots were evaluated for germination, seedling emergence in field and electrical conductivity tests, according to the procedures detailed below.

Germination: four replications of 50 seeds per lot were distributed in rolls of paper (substrate) moistened with deionized water equivalent to 2.5 times the dry substrate mass and kept in a germination chamber at $30{ }^{\circ} \mathrm{C}$ in the constant light. Seedling evaluations were performed 8 days after sowing; results were expressed as percentage of normal and abnormal seedlings (BRASIL, 2009).

Seedling emergence in the field: four replications of 50 seeds were manually distributed in $2.5 \mathrm{~m}$ rows at $3 \mathrm{~cm}$ depth and $0.05 \mathrm{~m}$ spacing between rows. Seedling emergence was recorded 14 days after sowing and the results were expressed as percentages (NAKAGAWA, 1999).

Electrical conductivity: four replications of 50 seeds per lot were individually weighed $(0.01$ $\mathrm{g}$ precision) and soaked in $75 \mathrm{ml}$ deionized water for $24 \mathrm{~h}$. Electrical conductivity was then measured on a MS Tecnopon mCA 150; results were expressed in $\mu \mathrm{S} \mathrm{cm}^{-1} \mathrm{~g}^{-1}$ (International Seed Testing Association, 2016). The electrical conductivity of the fast- imbibed seeds was determined considering also the conductivity performed immediately after the first $24 \mathrm{~h}$. 
A completely randomized design was used in a factorial scheme $3 \times 2$ (imbibitions methods and temperatures). The results analysis considered the average of the five soybean seeds lots for each treatment. Data were submitted to analysis of variance (ANOVA) at $5 \%$ probability. When statistically significant differences were reported $(P \leq 0.05)$, means were compared using the Tukey test at 5\% probability (Sisvar).

\section{DNA extraction and analysis}

Briefly, frozen cells were ground in liquid nitrogen, and genomic DNA was extracted from radicles (after each water uptake rate, $24 \mathrm{~h}$, $20{ }^{\circ} \mathrm{C}$, white constant light) according to the Kit DNA extraction mini spin 50 (KASVI ${ }^{\circledR}$ ). DNA electrophoresis was performed to assess DNA fragmentation. DNA samples (5 $\mathrm{mg}$ per lane) were loaded on a $2.0 \%$ agarose gel and stained with $0.2 \mathrm{mg}$ $\mathrm{ml}^{-1}$ ethidium bromide.

\section{RESULTS}

Seeds showed $13.4 \%$, in average (fresh weight basis). The overall uptake trend was similar for soybean seeds at 20 and $30{ }^{\circ} \mathrm{C}$ (Figure 1). In contrast, the dynamics of water entrance into the seeds showed differences according to water sorption isoterms (Figure 1). As hydration progressed, this phenomenon became more pronounced with the fast imbibition than by the other techniques, regardless the temperature. The seed water content on this treatment gradually increased about thirty percentage points during the first 8 hours (Figure 1).

At the same time, the seeds imbibed according to the control treatment (wet substrate) increased from $13 \%$ to about $35 \%$; and slow hydration gradually increased from $13 \%$ to about $24 \%$, as this technique expose the seed tissues to intermediate moisture contents for the whole imbibition period.

A similar effect was observed with the progress of time; fast imbibed seeds gained water

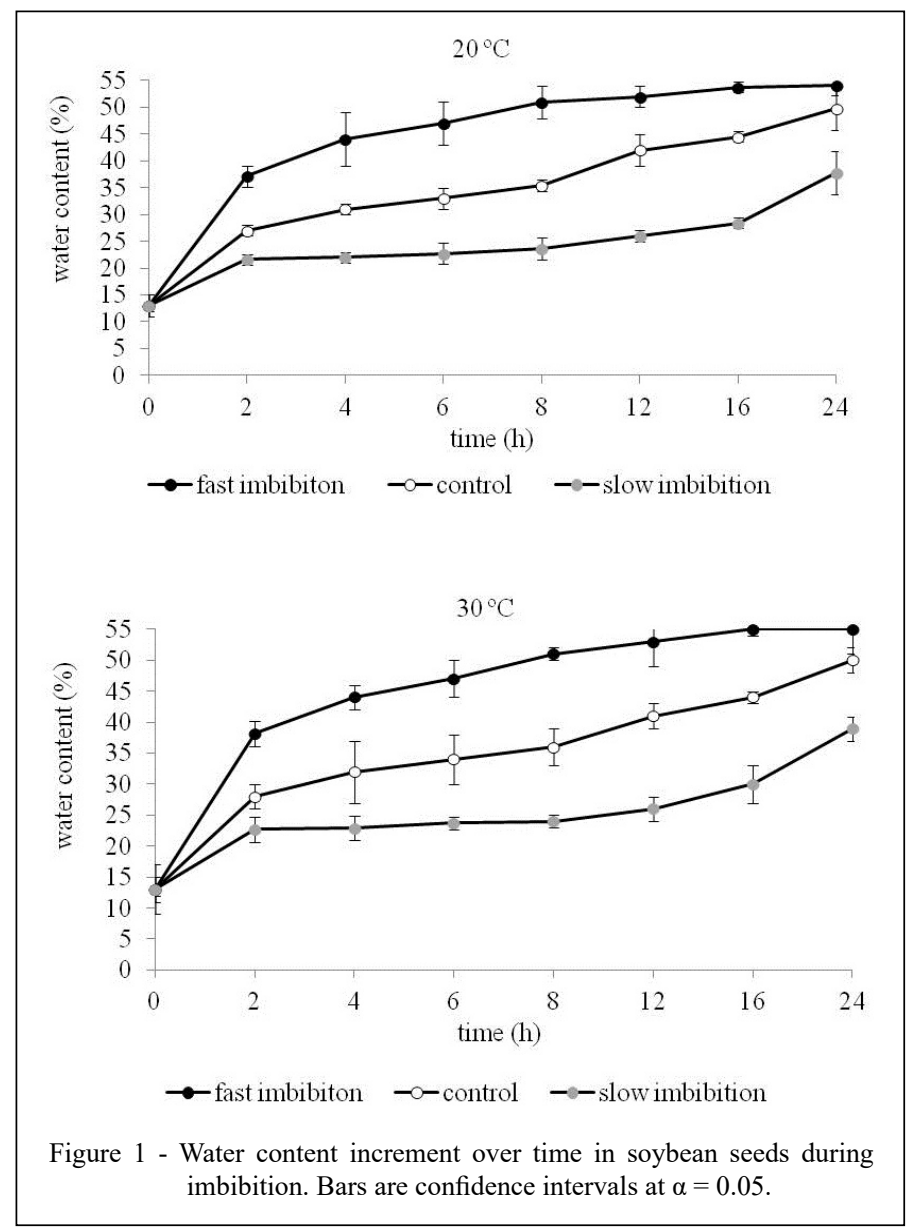

Ciência Rural, v.51, n.3, 2021. 
continuously (Figure 1), at the end of $24 \mathrm{~h}$ the fresh weight was about $55 \%$ at the both temperatures. Generally, such condition make difficult to evaluate whether the sorption experiment has reached equilibrium. In seeds from the control (wet substrate) a similar pattern was apparent; although, absolute values of water content were lower (49\%) (Figure 1). Slow hydration slightly increased after initial changes and seeds reached water contents almost constant for at least $24 \mathrm{~h}$ at both temperatures (Figure 1).

In order to evaluate if the course of water uptake by the seeds could affect the physiological seed quality, we evaluated characteristics tightly connected to the capacity of seeds to properly develop. In this way, the soybean seeds performance is affected by either water uptake or temperature (Figure 2).

Overall, the physiological response of seeds was negatively influenced by the fast water uptake rate. As a consequence of the course of seeds water uptake, seeds submerged in water (fast imbibition) showed low normal seedlings $(16 \%)$ than the other imbibition methods, regardless the temperature (Figure 2A). Although, the seeds submitted to slow imbibition (moist atmosphere) showed higher normal seedlings (80\%) than the control (75\%). Interestingly, during the fast imbibition at $20{ }^{\circ} \mathrm{C}$, the seeds became more sensitive to low temperature and the normal seedlings further decreased (Figure 2A).

When seeds rapidly imbibed, the capacity of germination decreased and the abnormal seedlings appeared, especially at high temperature (Figure 2B) whilst the control did not differ among the temperatures (Figure 2B). However, after slow imbibition the percentage of abnormal seedlings was lower than the other methods, but at $20^{\circ} \mathrm{C}$ the results of abnormal seedlings increased (35\%) (Figure 2B).

There were discernable differences in electrical conductivity between the slow water uptake and the faster imbibition methods, but no differences between temperatures (Figure 2C) and highlights the negative effect of fast water uptake on the ability to maintain the cell membranes integrity (Figure 2C). A similar pattern was observed with the field emergency; although, during slow imbibition no differences was apparent among the temperatures (on average $75 \%$ ) (Figure 2D). However, fast imbibition and the control at $20{ }^{\circ} \mathrm{C}$ showed lower field seeds performance (Figure 2D).

The water content - time of imbibition relationships observed at $20{ }^{\circ} \mathrm{C}$ were similar at 30 ${ }^{\circ} \mathrm{C}$ : there appeared to be no differences in sorption characteristics at the both temperatures. But we cannot deny the sensitivity in the performance of the

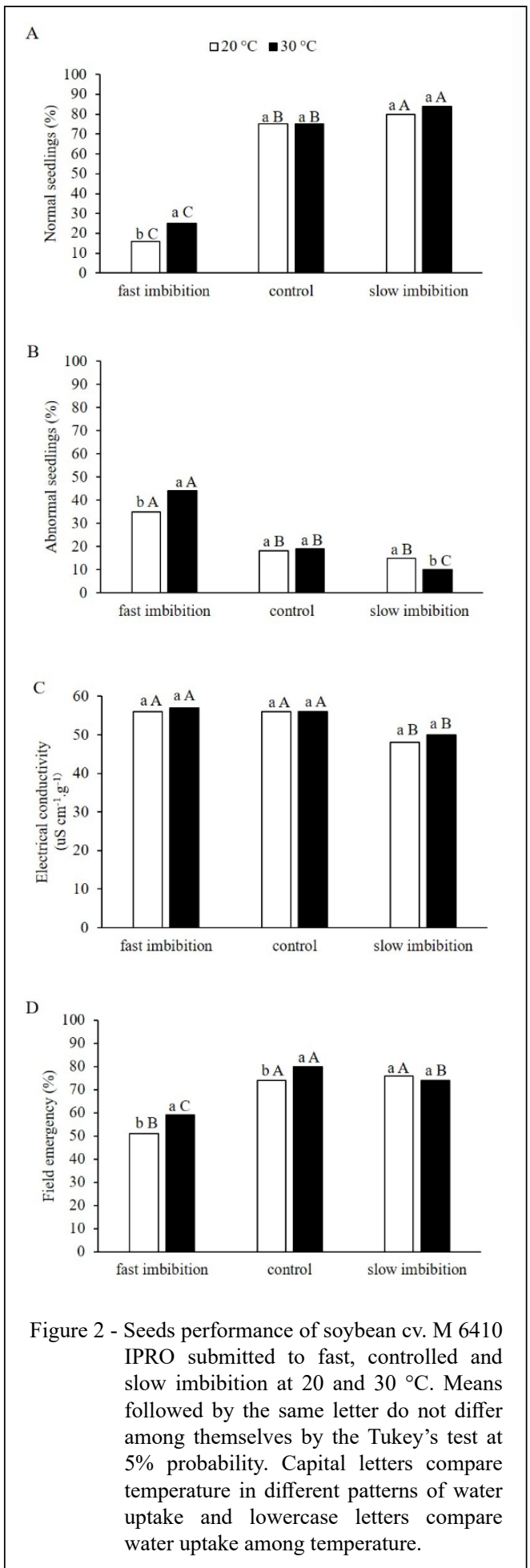

seeds exposed at the lowest temperature (Figure 2). To analyze further the change in the nucleic acid, we focused on genomic DNA extraction from the seeds submitted to each imbibitions method at $20^{\circ} \mathrm{C}$ and 
we examined the gel electrophoresis (Figure 3). Seeds submitted to fast imbibition showed intense DNA degradation followed by the control (moist substrate) (Figure 3). Upon fast imbibition seeds germinated lower than non fast-imbibed seeds, besides field performance and cell membrane integrity loss (Figure 2).

The fast imbibition resulted in a marked DNA degradation, whereas only a slight decrease of DNA integrity was detected in control (Figure 3), since the control-seeds still presented $75 \%$ normal seedlings. Nevertheless, it is worth noting that maintenance of DNA integrity was observed in slowimbibed seeds (Figure 3).

After rapid imbibition, seeds with only $16 \%$ of germination (normal seedlings) (Figure 2A) are henceforth referred to as 'non-viable'. Throughout

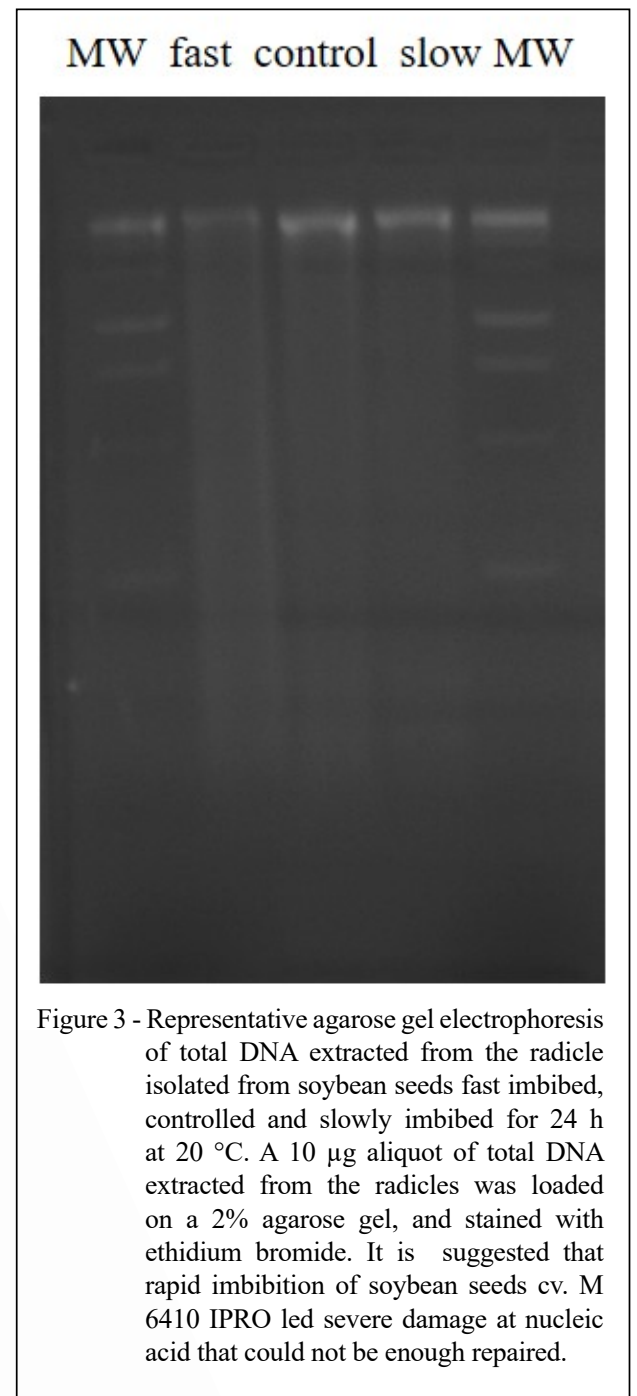

imbibition, the intensities of DNA degradation coinciding with loss of seed performance (Figure 3); further fast imbibition caused progressive viability loss. Instead, as slow imbibition occurs, there is maintenance of high seed germination ability $(80 \%)$ (Figure 2A) correlated to the maintenance of DNA integrity (Figure 3). However, seeds imbibed in wet substrate showed decrease of normal seedlings (75\%) and increased DNA degradation (Figure 3).

\section{DISCUSSION}

Water sorption describe the relationship between the water content and the time progress and were constructed according to the way of water uptake at 20 and $30^{\circ} \mathrm{C}$ to characterize the effect of the water uptake course into the seeds on that relationship. Sorption pattern of soybean seeds were similar among temperatures, but sorption characteristics vary with time progress according to the way of water entrance into the seeds (Figure 1).

Collectively, the uptake characteristics of soybean seeds were not related systemic uptake patterns according to the all of the imbibition methods. This could be attributed to the way of water entrance related to the time of seed imbibition. The changes in sorption characteristics of soybean seeds imply negative alterations of some useful biomarkers: seed germination and ability to develop normal seedlings in the field and cell membrane integrity. Other reports also indicated that environmental factors as temperature related to the rate of seed imbibition at the first $\sim 24 \mathrm{~h}$ in distilled water tend to cause loss of seed viability, as seen in soybean (SILVA \& VILLELA, 2011), maize (ZUCARELI et al., 2011), mung beans (SHUKLA et al., 2018) and rice (CHENG et al., 2017; XU et al., 2017).

Besides, temperature plays an important role in water uptake rate, reserve mobilization and reactivation of metabolism during early seed imbibition as demonstrated for wheat (KASHIWAKURA et al., 2016) and Ricinus communis (RIBEIRO et al., 2015). Rapid imbibition can induce stress during the transition of membranes from a rigid gel phase to a liquid crystalline phase, resulting in solute leakage (KRANNER et al., 2010), as seen in soybean seeds (Figure 2C). Furthermore, low temperature dramatically affected different metabolic pathways and reduced some physiological and biochemical processes of soybean seed before germination (CHENG et al., 2010).

Indeed, as rapidly water uptake occurs damages are concomitantly, so these changes can 
affect the natural process of DNA replication and transcription which in turn results in loss of cell viability (WATERWORTH et al., 2011). In this sense, we demonstrated that inability of normal seedlings formation and loss of field performance maintenance might be an indicator about DNA stability loss due to the rapid water uptake. Besides, the lower temperature exposure during imbibitions $\left(20{ }^{\circ} \mathrm{C}\right)$ may have accentuated the sensitivity of the seeds to the entry of rapid water culminating in normal seedlings reduced either in optimal (Figure 2A) or field conditions (Figure 2D). The primary event of injury by low temperature perhaps is the impaired reorganization of cell membrane in soybean seeds, since most of soybean cultivars are either chillingsensitive or moderately chilling-resistant, which results in severe economic loss due to low temperature before germination (CHENG et al., 2010).

DNA analysis enabled us to conclude firstly that the seeds water uptake dynamics resulted in DNA changes. Secondly, the abrupt water entrance into the seeds resulted in DNA degradation and gradually seeds imbibition allows the maintenance of DNA integrity (Figure 3). Nonetheless, there is a tight relationship between the maintenance of DNA integrity, capacity of germination and seed vigor maintenance and the water absorption dynamics in soybean seeds. Therefore, the increased DNA degradation could be attributed to the fast imbibition of the seeds as decrease in germination and seeds performance, besides the increase in the abnormal seedlings (Figure 2) most likely resulted from the disassembly of DNA structure.

Although, we do not have direct evidence that DNA degradation precedes and is causal for the losses in normal seedlings formation, the complete DNA degradation implies that these processes happen before cell death and not after. However, the changes in the pattern of DNA degradation of soybean seeds were clear according to the way of water entrance (Figure 1 and 3). In summary, DNA degradation may have triggered loss of soybean seed performance.

Lesions in the DNA contributed by various damaging agents, may result in changes in both the chemical and physical structures of DNA and thus generate both cytotoxic and genotoxic effects after/ or during seeds ageing (EL-MAAROUF-BOUTEAU et al., 2011), storage (MICHALAK et al., 2013) and imbibition (BALESTRAZZI et al., 2011; WATERWORTH et al., 2015) adversely affecting the seeds performance. To survive, organisms have evolved effective DNA damage detection, signaling and repair mechanisms (WATERWORTH et al.,
2011); following detection of DNA damage, repair is initiated by the recognition and excision of the damaged region and completed by DNA synthesis and ligation (MACOVEI et al., 2010; WATERWORTH et al., 2015). The complexity of the networks of DNA damage control/repair functions has been only partially elucidated in plants and concerns nucleotide and base excision repair, non-homologous end joining and homologous recombination which play specific roles, all of them being critical to ensure genome stability (VENTURA et al., 2012; WATERWORTH et al., 2015).

Nevertheless, the complete submersion of seeds in water - due to the rapid entry of water in seeds - promoted DNA damage (Figure 3) that, at least, was not sufficiently repaired to re-establish the normal seedling development and seed performance (Figure 2). This phenomenon have already been observed in seeds submitted to other abiotic stress, as shown in aged seeds from Triticum aestivum and Avena sativa (LEINO et al., 2009) and in desiccated and pre-moistened seeds of Campomanesia adamatium (DRESCH et al., 2015) and Sesbania virgata (MASETTO et al., 2015).

The pattern of DNA degradation (Figure 3 ) is considered as being a hallmark of passive or non-programmed cell death, thus suggesting that is not purely an accidental form of cell death as once thought. It is involved in mitochondrial dysfunction itself and a further exacerbation of the injury events and culmination in necrotic cell death. Because of the rapid decline of ATP generation and the rupture of mitochondria, the cell loses the ability to regulate plasma membrane integrity and necrosis fully ensues (KARCH \& MOLKENTIN, 2015).

The present research shows that loss of seed viability and performance after imbibition at the constant temperatures $\left(20^{\circ} \mathrm{C}\right.$ or $\left.30{ }^{\circ} \mathrm{C}\right)$ strongly depends on the rate of water uptake. Interestingly it is shown that the extent of DNA damage also depends on the rate of water entrance into the seeds, since DNA degradation varies with the way of water uptake. Based on these premises, our results showed that seed water uptake regulates the rate of DNA alteration in soybean seeds and may severely affect seeds performance.

\section{CONCLUSION}

Two important factors are related to imbibitional injury: the temperature and the rate at which water enters the soybean seed. Fast imbibition decrease soybean seeds performance and trigger DNA 
degradation, especially at $20{ }^{\circ} \mathrm{C}$. Seeds are better prepared for germination and have best preserved DNA if submitted early to slow imbibition.

\section{DECLARATION OF CONFLICTS OF INTERESTS}

The authors declare no conflict of interest. The founding sponsors had no role in the design of the study; in the collection, analyses, or interpretation of data; in the writing of the manuscript, and in the decision to publish the results.

\section{ACKNOWLEDGEMENTS}

The authors would like to thank the Coordenação de Aperfeiçoamento de Pessoal de Nível Superior (CAPES), Brazil for the financial support and PGAGRO-UFGD

\section{AUTHORS' CONTRIBUTIONS}

The authors contributed equally to the manuscript.

\section{REFERENCES}

BAHRY,C.A. et al. Physiological quality and imbibitions of soybean seeds with contrasting coats. Revista Ciência Agronômica, v.48, n.1, p.125-133, 2017. Available from: <http://www.scielo.br/ scielo.php?pid=S1806-66902017000100125\&script $=$ sci_arttext $>$. Accessed: Jul. 20, 2019.

BALESTRAZZI, A. et al. Genotoxic stress and DNA repair in plants: emerging functions and tools for improving crop productivity. Plant Cell Reports, v.30, n.3, p.287-295, 2011. Available from: <https://link.springer.com/content/pdf/10.1007/ s00299-010-0975-9.pdf>. Accessed: Jul. 28, 2019.

BALESTRAZZI, A. et al. DNA repair and telomere maintenance during seed imbibition: correlation of transcriptional patterns. Telomere Telomerase, v.2, p.e496, 2015. Available from: <http:// citeseerx.ist.psu.edu/viewdoc/download?doi=10.1.1.965.4732\&re $\mathrm{p}=$ rep1\&type=pdf $>$. Accessed: Sep. 15, 2019.

BEWLEY, J. D. et al. Seeds: physiology of development, germination and dormancy. Springer Science \& Business Media, 2013.

Brasil. Regras para Análise de Sementes. MAPA/ACS: Ministério da Agricultura, Pecuária e Abastecimento, Brasília: Brazil. 2009.

CAVARIANI, C. et al. Speed of hydration as affected by seed coat characteristics in soybean of different cultivars and locations. Revista Brasileira de Sementes, v.31, n.1, p.30-39, 2009. Available from: <http://www.scielo.br/scielo.php?pid=S180666902017000100125\&script=sci arttext $>$. Accessed: Sep. 15, 2019.

CHENG, J. et al. Proteomic analysis of soybean [Glycine max (L.) Meer.] seeds during imbibition at chilling temperature. Molecular Breeding, v.26, n.1, p.1-17, 2010. from: <https:// link.springer com/content/pdf/10.1007/s11032-009-9371-y.pdf $>$. Accessed: Jun. 12, 2019.

CHENG, J. et al. Identification of genes involved in rice seed priming in the early imbibition stage. Plant Biology, v.19, n.1, p.61-69, 2017. Available from: <https://onlinelibrary.wiley.com/ doi/full/10.1111/plb.12438>. Accessed: Jul. 28, 2019.

DRESCH, D. M.; et al. Campomanesia adamantium (Cambess.) O. Berg seed desiccation: influence on vigor and nucleic acids. Anais da Academia Brasileira de Ciências, v.87, n.4, p.22172228, 2015. Available from: <http://www.scielo.br/scielo. php? pid $=$ S0001-37652015000502217\&script $=$ sci_arttext $>$. Accessed: Oct. 15, 2019.

EL-MAAROUF-BOUTEAU, $H$. et al. DNA alteration and programmed cell death during ageing of sunflower seed. Journal of Experimental Botany, v.62, n.14, p.5003-5011, 2011. https:// academic.oup.com/jxb/article/62/14/5003/479224>. Accessed: Sep. 15, 2019.

GRIS, C. F. et al. Physiological quality and lignin content in the coat seeds of conventional and RR transgenic soybean submitted to different harvest periods. Ciência e Agrotecnologia, v.34, n.2, p.374-381, 2010. Available from: <https://www.cabdirect.org/ cabdirect/abstract/20103157572>. Accessed: Jul. 22, 2019.

ISTA. International rules for seed testing. ISTA: Bassesrdorf. 2016.

KARCH, J.; MOLKENTIN, J.D. Regulated necrotic cell death. Circulation Research, v.116, n.11, p. 1800-1809, 2015. Available from: <https://www.ahajournals.org/doi/full/10.1161/ circresaha.116.305421>. Accessed: Jul. 15, 2019.

KASHIWAKURA, Y. et al. Highly sprouting-tolerant wheat grain exhibits extreme dormancy and cold imbibition-resistant accumulation of abscisic acid. Plant and Cell Physiology, v.57, n.4, p.715-732, 2016. Available from: <https://academic.oup.com/ pcp/article/57/4/715/2461084>. Accessed: Oct. 15, 2019.

KRANNER, I. et al. What is stress? Concepts, definitions and applications in seed science. New Phytologist, v.188, n.3, p.655673, 2010. Available from: <https://nph.onlinelibrary.wiley.com/ doi/epdf/10.1111/j.1469-8137.2010.03461.x>. Accessed: Sep. 15, 2019.

LEINO, M. et al. DNA preservation and utility of a historic seed collection. Seed Science Research, v.19, n.3, p.125-135, 2009. Available from: < https://www.cambridge.org/core/journals/seedscience-research/article/dna-preservation-and-utility-of-a-historicseed-collection/EB4C26BAB4293EBA3F5C7417B71404A7>. Accessed: Jul. 22, 2019.

MACOVEI, A. et al. The tyrosyl-DNA phosphodiesterase gene family in Medicago truncatula Gaertn.: bioinformatic investigation and expression profiles in response to copper-and PEG-mediated stress. Planta, v.232, n.2, p.393-407, 2010. Available from: $<$ https://link.springer.com/article/10.1007/s00425-010-1179-9>. Accessed: Jul. 23, 2019.

MASETTO, T. E.; et al. Loss and re-establishment of desiccation tolerance in the germinated seeds of Sesbania virgata (Cav.) (Pers.). Acta Scientiarum. Agronomy, v.37, n.3, p.313-320, 2015. Available from: $<$ http://www.scielo.br/scielo.php?pid=S180786212015000300313\&script=sci_arttext $>$. Accessed: Oct. 25, 2019.

MICHALAK, M. et al. Global changes in DNA methylation in seeds and seedlings of Pyrus communis after seed desiccation and storage. PloS one, v.8, n.8, 2013. Available from: $<$ https:// www.ncbi.nlm.nih.gov/pmc/articles/PMC3734228/>. Accessed: Oct. 23, 2019. 
NAKAGAWA, J. Vigor tests based on seedlings assessment [in Portuguese]. In KRZYZANOWSKI, F. C. et al. (eds), Seed Vigour: Concepts and Tests, pp. 2.1-2.21. Londrina, Brazil: ABRATES. 1999.

NOBLET, A. et al. Chilling temperature remodels phospholipidome of Zea mays seeds during imbibition. Scientific reports, v.7, n.1, p.1-12, 2017. Available from: < https://www.nature.com/articles/ s41598-017-08904-z>. Accessed: Jul. 29, 2019.

NONOGAKI, H. Seed germination-the biochemical and molecular mechanisms. Breeding Science, v.56, n.2, p.93-105, 2006. Available from: <https://www.jstage.jst.go.jp/article/ jsbbs/56/2/56_2_93/_article/-char/ja/>. Accessed: Nov. 30, 2019.

RIBEIRO, P. R. et al. Metabolite profiling of the oilseed crop Ricinus communis during early seed imbibition reveals a specific metabolic signature in response to temperature. Industrial Crops and Products, v. 67, p. 305-309, 2015. Available from: <https:// www.sciencedirect.com/science/article/pii/S0926669015000692>. Accessed: Dec. 05, 2019.

ROSSETTO, C. A. V. et al. Evaluation of the performance of soybean seeds during the early stage of the germination process. Scientia Agricola, v.54, n.1-2, p.106-115, 1997. Available from: <http://www.scielo.br/scielo. php?pid=S0103-90161997000100015\&script $=$ sci_arttext $>$. Accessed: Oct. 24, 2019.

SHUKLA, N. et al. Hydro-priming methods for initiation of metabolic process and synchronization of germination in mung bean (Vigna radiata L.) Seeds. Journal of Crop Science and Biotechnology, v.21, n.2, p.137-146, 2018. Available from: $<$ https://link.springer.com/article/10.1007/s12892-018-0017-0>. Accessed: Dec. 05, 2019.

SILVA, K. da R. G.; VILLELA, F. A. Pre-hydration and evaluation of the physiological potential of soybean seeds. Revista Brasileira de Sementes, v.33, n.2, p.331-345, 2011. Available from: <https:// www.cabdirect.org/cabdirect/abstract/20113222085>. Accessed: Sep. 24, 2019

VENTURA, L. et al. Understanding the molecular pathways associated with seed vigor. Plant Physiology and Biochemistry, v.60, p.196-206, 2012. Available from: $<$ https://www.sciencedirect. com/science/article/pii/S0981942812002100>. Accessed: Oct. 15, 2019.

WATERWORTH, W. M. et al. Repairing breaks in the plant genome: the importance of keeping it together. New Phytologist, v.192, n.4, p.805-822, 2011. Available from: <https://nph. onlinelibrary.wiley.com/doi/full/10.1111/j.1469-8137.2011.03926. $\mathrm{x}>$. Accessed: Nov. 24, 2019.

WATERWORTH, W. M.; BRAY, C. M.; WEST, C. E. The importance of safeguarding genome integrity in germination and seed longevity. Journal of Experimental Botany, v.66, n.12, p.3549-3558, 2015. Available from: < https://academic.oup.com/ jxb/article/66/12/3549/524229 > . Accessed: Jul. 15, 2019.

WEITBRECHT, K. et al. First off the mark: early seed germination. Journal of Experimental Botany, v.62, n.10, p.3289-3309, 2011. Available from: <https://academic.oup.com/ jxb/article/62/10/3289/478838 >. Accessed: Nov. 29, 2019.

XU, E. et al. Proteomic analysis reveals proteins involved in seed imbibition under salt stress in rice. Frontiers in Plant Science, v.7, p.2006, 2017. Available from: <https://www.frontiersin.org/ articles/10.3389/fpls.2016.02006/full>. Accessed: Sep. 25, 2019.

ZUCARELI, C. et al. Métodos e temperaturas de hidratação na qualidade fisiológica de sementes de milho. Revista Ciência Agronômica, v.42, n.3, p.684-692, 2011. Available from: $\quad<$ http://www.scielo.br/scielo.php?pid=S1806$66902011000300015 \&$ script $=$ sci_arttext\&tlng=pt $>$. Accessed: Jan. 15, 2018. 